\section{Cariology in Curriculum of Brazilian Dental Schools}

Naiara de Paula Ferreira-Nóbiloº ${ }^{1}$ Maria da Luz Rosário de Sousa ${ }^{1}$, Jaime Aparecido Cury ${ }^{2}$
'Department of Community Dentistry, Piracicaba Dental School, UNICAMP - University of Campinas, Piracicaba, SP, Brazil ${ }^{2}$ Department of Physiological Sciences, Piracicaba Dental School, UNICAMP - University of Campinas, Piracicaba, SP, Brazil

Correspondence: Prof. Dr. Jaime Aparecido Cury, Av. Limeira 901 P.O. Box 52, 13414-903 Piracicaba, SP, Brazil. Tel: +55-19-21065302. email: jcury@unicamp.br

Key Words: dental caries, teaching, curriculum.

\section{Introduction}

Although the mechanisms of dental caries development and prevention are well known, and there has been a decline in incidence of the disease in recent decades, it continues to be one of the most prevalent problems in dentistry in all parts of the world (1-5).

Dental caries is unevenly distributed among different population groups, being focused on the most vulnerable groups, in addition to being unevenly distributed between different countries (6). In developing countries, such as Latin America, social inequities, such as difficulties to access to health care and educational limitations, are responsible for the persistence of caries as a major public health problem. Nevertheless, these countries have joined the fight against the disease by Alliance Chapter and them to learn from each other through sharing experiences their (7). In Brazil, the national epidemiological surveys on oral health inequalities between population groups revealed, specially regarding family income and Brazilian region (8).

Thus, considering that the disease continues to present a significant social and economic impact, it is imperative to monitor and evaluate the insertion of the field knowledge of Cariology, comprising scientific understanding of the etiology, pathogenesis, prevention and treatment of caries, as well as events related to other dental tissue disorders in the curricular structure of dental students (6).
In this context, various attempts have recurrently been made throughout the world to understand the teaching scenario. The curricula of Cariology in Europe seem to be better structured and currently a unique curriculum has been designed to be adopted in all the European dental schools $(5,6)$. In North America $(9,10)$ and Japan $(11)$ the findings on the management of education were similar, indicating the contents Cariology are not also contemplated over the undergraduate and present diversity among dental schools. As regards dental schools of Latin American Spanish-speaking countries include content on cariology with different workloads and that there is absence/ deficiency some issues related to curricula Cariology (12). Brazil is the only country in Latin America that has not been fully investigated. Given its insertion on the world political scene and its large land area, which includes five administrative regions independents politically, it becomes necessary to perform works that deal with the teaching of Cariology in this country to truly understand the level of teaching in Latin America and worldwide.

An important tool in the context of teaching and learning is the Pedagogical Project of Undergraduate Course (PPC), which generally defines the fundamentals that guide the formation of each school. In Brazil, the mandatory element of this document are the summaries of all disciplines of the course, which contain the subjects 
to be taught in courses.

Knowing that the summaries are characterized as an important source of information about health education, the aim of this study was to identify the insertion of the content relative to Cariology in the curricular flowcharts of undergraduate courses at public dental schools in the country.

\section{Material and Methods}

The research was approved by the Research Ethics Committee of FOP/UNICAMP (Protocol \#002/2012). The strategy used in this study was the documentary analysis, to research the summaries of all disciplines from the PPC. A survey of dental schools in the country was conducted from their registration at the Federal Council of Dentistry (CFO), which indicated the existence of 205 registered dental schools (13). However, it was noted that some dental schools were not in operation, and others had duplicated registration at the Council (different names with the same street address). Up to July 2013, there were 191 dental schools operating in the country, considering public and private dental schools.

The data source would therefore be the Ministry of Education (MEC), since this ministry requires the dental schools in the country to subimit the PPC document, which contains the discipline menus for authorization of the courses. However, the MEC does not yet have a unified system that would make this search possible. Therefore, the authors identified the schools in the country that made the required material available on their websites. About $80 \%$ of dental schools, both public and private, did not allow free access to the PPC and/or discipline menus.

Attempts were made to obtain material by means of exhaustive phone calls to the course coordinators, and subsequently contacts via e-mail. Few coordinators returned the requested PPC (fewer than 40\% of dental schools in the country, with an even lower percentage among private dental schools) and, for this reason, we chose to perform the analysis only on the material obtained from the public dental schools $(n=47)$, excluding the 144 private dental schools in operation. After repeated contacts with the coordinators of public dental schools, a rate of over $90 \%$ adherence was achieved.

For analysis of the data, the dental schools were grouped according to the geographic regions of Brazil: Northern (3 dental schools), Northeastern (16 dental schools), Mid-Western (3 dental schools), Southeastern (17 dental schools) and Southern (8 dental schools) regions. Three dental schools in the Southeastern region did not provided their menus.

Descriptive analysis was performed, and considering other published studies on Cariology teaching on the international scene $(5-7,9,11)$, the following items were established for analysis: number of dental schools that include content related to Cariology in their curricula, total average hours of undergraduate courses; workload of disciplines that address the theme of Cariology; distribution of disciplines that include content in the basic, clinical and public health cycles; existence of specific Cariology discipline and/or specific department, and existence of bibliographic indication directly related to Cariology.

The definition of Cariology as "science dedicated to studying the etiology, pathogenesis, prevention and treatment of caries and other events related to dental tissue disorders" (5), guided the analysis and discussion of this work.

\section{Results}

Of the 47 public dental schools operating in Brazil, the summaries of all disciplines of 44 of them were located (response rate: 93.6\%). All the dental schools in the country contemplate content related to Cariology in their disciplines, distributed in the three learning cycles (basic, clinical and public health), in specific disciplines, and present specific books for recommended reading on Cariology. None of the dental schools investigated had a Department of Cariology and the related disciplines (including the specific disciplines) were distributed among various departments.

Table 1 shows the distribution of average total workload of undergraduate courses and disciplines related to Cariology. Among the disciplines with content related to Cariology, the distribution of workload ranged from $245 \mathrm{~h}$ the Southeastern region to $442.2 \mathrm{~h}$ in the Southern region. The Northern region was the only one in the country that did not have specific disciplines in any of its public dental schools. The Northeast region had the highest percentage of dental schools with specific disciplines (44.0\%), followed by the Mid-Western and Southeastern regions (both with $33.3 \%$ of the dental schools). Although the Southern region had a low percentage of dental schools with specific disciplines (16.7\%), it is the region that has the highest workload of specific disciplines per school.

Table 2 shows the grouping of disciplines that addressed the theme according to the learning cycle and specific disciplines. Only the content related to Cariology was highlighted. In the basic cycle disciplines, there was predominance of Microbiology/Immunology (36.0\%); in the clinical cycle, Dentistry disciplines (35.0\%); and in the public health cycle, Community Health disciplines (54.0\%). Among the specific disciplines, over half of those identified were denominated Cariology (56.0\%), followed by Dental Caries (31.0\%) and Others (13.0\%) (Fig. 1). 


\section{Discussion}

The data collection for this study was performed in about two years, and the delay was because of the great difficulty in obtaining the necessary material. The initial goal was to make a documentary analysis of all the dental schools in the country, both public and private, but bureaucratic and political obstacles made this collection unfeasible, being considered in this study only public dental schools.

After repeated contacts with the coordinators of the public dental schools, a rate of over $90 \%$ adherence was obtained. Three dental schools in the Southeastern region did not provided their menus; in two of them the coordinators agreed to send them (but they did not do so) and in the other one participation was declined for purely political reasons, unrelated to the importance of this work on the national scenario. It is emphasized that in the specific case of public schools, these should make consultation available freely on demand, according to the Law on Access to Information (14). Nevertheless, this study aimed to the census of public dental schools in the country for the investigations presented here, seeking to identify the realities of different geographical regions.

Differently from work carried out in other parts of the world, who used sending questionnaires to schools, in this study we chose to consultation with PPC, it is the most reliable strategy found because it is an official document, free of possible subjectivities or interference of respondents.

The hallmark of Dentistry, as a science and profession, has been related to studies with reference to caries disease, which continues to be the most prevalent of its problems. All the participating dental schools had courses with content related to Cariology (with a course duration of $4,369 \mathrm{~h}$ of content related to Cariology, varying from 245 $\mathrm{h}$ in the Southeastern region to $442 \mathrm{~h}$ in the Southern region), although none of them had a specific department of Cariology, as is the case in other parts of world $(7,8$,
11). The authors consider that the existence of a specific department of Cariology will not result in better teaching this thematic, since its contents are common to various disciplines throughout the undergraduate course.

The contents identified were distributed throughout the undergraduate courses in disciplines of the three cycles of learning: in the basic cycle there is a predominance of menus that deal with the pathogenesis of the disease, biochemical processes in the development of the disease and microbiological components involved; in the clinical cycle, the focus is on items related to the diagnosis and treatment of disease, going through the use of dental materials, and in the collective health cycle, notions of "prevention" of disease, epidemiology, risk assessment and concerning health promotion aspects. Among the menus of specific disciplines, we note that they sought to encompass all the contents, covering the aspects of disciplines in the different cycles. In other parts of the world is also noted that the distribution of the contents does not occur in an equitable way between cycles of learning $(6,9-12)$, which can compromise the overall concern of students - which is why a group of researchers from Europe has proposed creating a unique curriculum of Cariology (5).

The concept of Cariology adopted in this study is likely to be covered during training of the student, although fragmented among the cycles; i.e., in the basic cycle the aspects were related to etiopathogenesis and other disorders; in the clinical cycle, to prevention and treatment; and in the public health cycle, to the preventive aspects of dental caries and other disorders. This fact may hinder the full understanding by students in training, considering possible difficulty they have in the construction of all knowledge, since they have seized a piecemeal fashion (15).

In all the regions of Brazil, except for the Southern region, dental schools concentrate the content related to the theme in the disciplines of the clinical cycle, which generally begins just before halfway through the course, and

Table 1. Average undergraduate workload (h) and disciplines related to the theme of Cariology according to geographical regions of Brazil (2013)

\begin{tabular}{|c|c|c|c|c|c|c|}
\hline \multirow{2}{*}{$\begin{array}{l}\text { Region/Dental } \\
\text { school (n) }\end{array}$} & \multirow{2}{*}{$\begin{array}{l}\text { Undergraduate } \\
\text { workload }\end{array}$} & \multirow{2}{*}{$\begin{array}{l}\text { Workload related } \\
\text { disciplines }\end{array}$} & \multirow{2}{*}{$\begin{array}{c}\text { Workload of } \\
\text { specific disciplines }\end{array}$} & \multicolumn{3}{|c|}{ Related Disciplines } \\
\hline & & & & $\begin{array}{l}\text { Basic cycle } \\
\text { workload }\end{array}$ & $\begin{array}{l}\text { Clinical cycle } \\
\text { workload }\end{array}$ & $\begin{array}{l}\text { Public health } \\
\text { cycle workload }\end{array}$ \\
\hline Northern (3) & 4060 & 274.0 & 0 & 80.0 & 128.0 & 66.0 \\
\hline Northeastern (16) & 4189 & 338.4 & 68.5 & 72.3 & 125.3 & 72.3 \\
\hline Mid-Western (3) & 4323 & 310.3 & 48.0 & 77.3 & 105.0 & 80.0 \\
\hline Southeastern (14) & 4676 & 245.0 & 45.0 & 64.0 & 88.0 & 48.0 \\
\hline Southern (8) & 4598 & 442.2 & 147.3 & 94.7 & 136.0 & 64.2 \\
\hline TOTAL (44) & 4369.2 & 322.0 & $77.2^{\mathrm{a}}$ & 77.7 & 116.5 & 66.1 \\
\hline
\end{tabular}

among the regions that teach specific disciplines. 
Table 2. Disciplines that contemplated the theme investigated according to learning cycle. Brazil, 2013.

\begin{tabular}{|c|c|c|c|}
\hline Learning cycle & \multicolumn{2}{|r|}{ Disciplines } & Content of Menus \\
\hline \multirow{7}{*}{ Basic } & \multicolumn{2}{|c|}{$\begin{array}{l}\text { Microbiology/ } \\
\text { Immunology }\end{array}$} & $\begin{array}{l}\text { Streptococci (mutans, salivarius, sanguis). Evaluation test of Streptococcus } \\
\text { mutans. Total microorganisms from saliva. Immunological aspects of dental caries. }\end{array}$ \\
\hline & \multicolumn{2}{|c|}{ Biochemistry } & $\begin{array}{l}\text { Biochemistry of saliva. Diet. Dental plaque. De-remineralization/ } \\
\text { Erosion. Fluoride: intake, metabolism and toxicity. Anti-plaque agents. } \\
\text { Mechanism of action of fluoride in dental caries control. }\end{array}$ \\
\hline & \multirow{2}{*}{ Diagnosi } & Diagnosis & Identification of lesions in the oral cavity, carious and non-carious. \\
\hline & & Stomatology & Semiology of the enamel organ injuries: dental caries and other. \\
\hline & \multicolumn{2}{|c|}{ Pathology } & Pathology of dental caries. \\
\hline & \multirow{2}{*}{ Others } & Histology & Enamel, dentin, dental pulp. Dental caries. \\
\hline & & Pharmacology & Chemical control of biofilm. \\
\hline \multirow{7}{*}{ Clinical } & \multicolumn{2}{|c|}{ Dentistry } & $\begin{array}{l}\text { Surgical interventions with the aim of treatment and conservation of dental } \\
\text { elements, patients with carious lesions and/or larger structures, preserving } \\
\text { the preventive principles inherent to maintaining good oral health status. }\end{array}$ \\
\hline & \multicolumn{2}{|c|}{$\begin{array}{l}\text { Pediatric } \\
\text { Dentistry }\end{array}$} & $\begin{array}{l}\text { Preventive treatment: fissure sealants and fluoride varnishes. } \\
\text { Treatment of carious lesions. Influence of diet on demineralization and } \\
\text { remineralization of dental tissues. Orientation and training for parents } \\
\text { and/or guardians about the various oral manifestations in children. }\end{array}$ \\
\hline & \multirow{2}{*}{ Clinical } & Integrated Clinical & $\begin{array}{l}\text { Transdisciplinary clinical care through the application of educational, } \\
\text { preventive and curative measures of the main oral diseases (dental caries, } \\
\text { periodontal disease and malocclusion) level of medium complexity. }\end{array}$ \\
\hline & & Preclinical & $\begin{array}{l}\text { Factors involved in the development of caries (saliva and diet). Rational use of } \\
\text { fluoride. Criteria for removal of carious dentin. Adequacy of the oral environment. } \\
\text { Therapeutic decision for invasive and noninvasive clinical practice. }\end{array}$ \\
\hline & \multirow{3}{*}{ Others } & Radiology & Radiographic study of the dental element, including dental caries. \\
\hline & & Fixed Prosthodontics & Restore teeth largely destroyed by caries (crown and root). \\
\hline & & Dental Materials & Materials used in dental caries prevention. \\
\hline \multirow{9}{*}{ Public Health } & \multicolumn{2}{|c|}{$\begin{array}{l}\text { Community } \\
\text { Health }\end{array}$} & $\begin{array}{l}\text { Dental caries: physical and chemical factors, host factors, factors of the substrate, } \\
\text { the agent factors, indices and diagnoses. Epidemiology and epidemiological survey. } \\
\text { Fluoride: history, mechanism of action and metabolism, toxicology. Fluorosis - } \\
\text { indexes and epidemiology. Caries activity tests. Levels of prevention and application. }\end{array}$ \\
\hline & \multicolumn{2}{|c|}{$\begin{array}{l}\text { Preventive } \\
\text { Dentistry }\end{array}$} & $\begin{array}{l}\text { Preventive methods applicable to oral diseases at individual and collective levels: } \\
\text { systemic and topical fluorides, health education, pit and fissure sealants, chemical } \\
\text { and mechanical control of dental biofilm. Preventive dental health policies in Brazil. }\end{array}$ \\
\hline & \multicolumn{2}{|c|}{ Epidemiology } & Epidemiology. Prevalence of caries. Oral health epidemiology. Indexes and indicators. \\
\hline & \multirow{4}{*}{$\begin{array}{l}\text { Life } \\
\text { cycles }\end{array}$} & Human Health & $\begin{array}{l}\text { Dental caries: concepts, factors, assessment of risk versus cariogenic activity, } \\
\text { prevention of dental caries, individual and professional control, topical and systemic } \\
\text { action of fluoride, chemical methods, physiology, biosecurity and toxicity of chemical } \\
\text { agents. Therapies associated with the control of dental caries. Dental fluorosis. }\end{array}$ \\
\hline & & Geriatric Dentistry & Root caries. \\
\hline & & Children and Adolescents & $\begin{array}{l}\text { Preventive and curative medical procedures of the most prevalent } \\
\text { oral problems: caries, gingivitis and malocclusion. }\end{array}$ \\
\hline & & Adult Care & $\begin{array}{l}\text { Study of diagnosis and treatment of dental caries and } \\
\text { its consequences for the tooth structure. }\end{array}$ \\
\hline & \multirow[b]{2}{*}{ Others } & Comprehensive Care & Plaque control and application of fluoride gel. Sealants. \\
\hline & & Integrated seminars & $\begin{array}{l}\text { Plaque formation and activity. Epidemiology of dental caries. Caries and its } \\
\text { implications. Clinical signs of dental caries. Risk factors and determinants. } \\
\text { Clinical, radiographic and histological aspects of dental caries. Diagnosis of caries. } \\
\text { Risk assessment. Treatment of caries. Molecular biology and dental caries. }\end{array}$ \\
\hline
\end{tabular}


extends to the end of it. A greater workload that includes the theme in this cycle may encourage the overtone welfare practice of the profession, placing value on the healing aspects in combatting caries disease. It is also troubling that the disciplines of Public Health cycle related to the topic menus do not show in terms of their social determination of dental caries, which appears to be essential for the formation and complete understanding of the disease. This context of dental education may aggravate difficulties for establishing the guidelines of the Brazilian National Oral Health Policy (16), which recommends training of general practitioners, committed to the Brazilian social problems and having humanized approaches to confront the most prevalent oral diseases such as dental caries.

The workload of courses with content related to Cariology was similar in both the basic and public health cycle. It is emphasized that the disciplines of the basic cycle were concentrated on the beginning of the course, while those in the collective health cycle are distributed from beginning to end of the course. Perhaps the marginalization of the basic cycle disciplines during the progression of the undergraduate course may impair the full performance of these students against the disease, since consolidation of the knowledge of caries, especially of its etiopathogenesis, clearly explained in the basic concepts, may be "forgotten" or overlooked by the time these students complete the course. Thus, it would be recommended the use of integrated curricula (17) and active methods of teaching and learning (such as Problem-Based Learning) (18) to allow that the contents taught during the undergraduate course can be constantly reviewed and widened until it is completely understood by students.

The discussion of workload in the learning cycle should be made with caution, as the mere indication of content related to Cariology in the disciplines does not mean that it will be addressed throughout the workload. That is, a discipline that has content related to Cariology in its menu, and may approach it in only one class, and will have accounted for its total workload in this study. Thus, it seems more prudent to discuss the workload of specific disciplines because these would contemplate content related to Cariology in their total workload.

In almost all of the Brazilian public dental schools, the specific subjects are taught from the beginning through to the middle of the course; that is, the contents of these disciplines, although they cover all the aspects involved caries disease and correlated to Cariology, also seem to be marginalized, as occurs with the disciplines of the basic cycle. Only two dental schools had more than one specific discipline (in the Southeastern region, one dental school had 6 specific disciplines, and in the Southern region, one dental school had 3 specific disciplines), which were distributed from beginning to end of the course.

Is important to consider the political gain in including a Cariology discipline in several dental schools in Brazil. This would be a territorial advancement, recognition of the importance of a systematic study of caries in view of the social and market needs found, in addition to the possibility of Cariology becoming an area with the greater potential for raising funds for research. On the other hand, one

\section{Basic cycle}

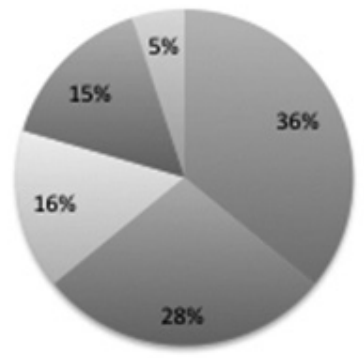

= Microbiology

= Biochemistry

- Diagnosis

- Pathology

=thers
A

\section{Clinical cycle}

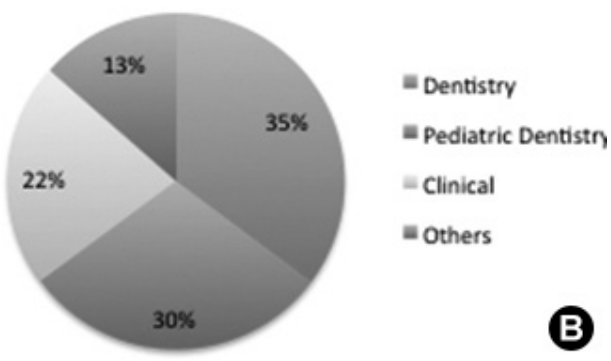

Specific Disciplines

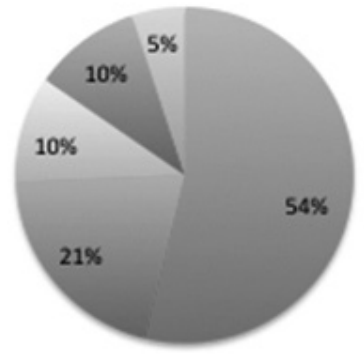

Community Health

a Preventive Dentistry

Epidemiology

- Lifecycles

others

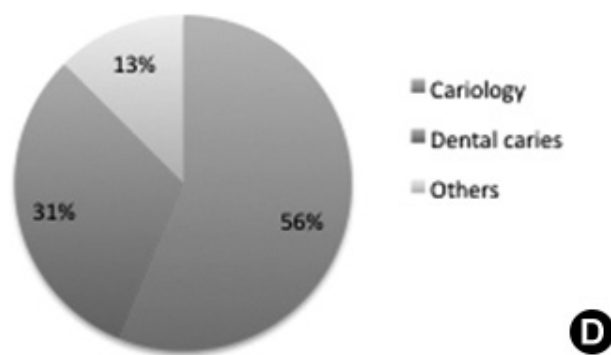

Figure 1. Percentage distribution of subjects related to Cariology according to learning cycle and specific disciplines in undergraduate courses. 
should not ignore the fact that the creation of watertight disciplines is in counter-flow to the recommendations of an integrated curriculum (19). The existence of a specific discipline can become an impediment to the endeavor to promote interdisciplinary teaching and learning, because it may cause a sense of non-responsibility in teachers who are not directly connected with this discipline, with regard to the approach to Cariology in the disciplines they teach, which may result in a non-integral perception of the disease. A possible solution to this question would be, if possible, to break with the logic of disciplines and curricular grids, establishing an axis of training in curricular flows that would incorporate Cariology as a guiding core of training.

When looking at the examples of discipline menus, we note that the contents are recurrent in different cycles (e.g., contents related to the use of fluoride as "preventive" strategies are taught in the basic, clinical and public health cycles, in addition to specific disciplines). To begin with, Cariology could be a point of intersection of interdisciplinary activities, so that cohesive contents could be taught in the different disciplines. To do so, it would be necessary to have an interaction between teachers of different cycles, and they would be advised to adopt the same philosophy towards the disease, with a view to the integral teaching of Cariology.

In conclusion, despite the inclusion of content related to Cariology in the undergraduate course flowcharts of Brazilian public dental schools in specific disciplines and in disciplines distributed in the basic, clinical and public health cycles, there is an emphasis on clinical cycle disciplines. This fact may not be promoting the integrated formation of students, which could be contributing to reflect the inequalities of the disease in the country

\section{Resumo}

As razões para as iniquidades da cárie, mundialmente reconhecidas, podem estar relacionadas ao modo como Cariologia tem sido ensinada nas faculdades de Odontologia. No Brasil, as principais universidades em termos de ensino de saúde, são as públicas. 0 objetivo deste trabalho foi identificar a inserção dos conteúdos de Cariologia nos fluxos curriculares de cursos de graduação das faculdades públicas de Odontologia do pais. A pesquisa foi realizada em 2013 buscando identificar as realidades de diferentes regiões geográficas, visando o censo de faculdades públicas. Foi realizada análise documental dos ementários das disciplinas, identificando: número de faculdades que incluem conteúdos relacionados à Cariologia em seus curriculos; carga horária total média dos cursos de graduação e de disciplinas que contemplam a temática; distribuição das disciplinas nos ciclos de formação profissional (básico, clínico e de saúde coletiva); existência de disciplina e/ou departamento específico; verificação de indicação bibliográfica relacionada diretamente à Cariologia. A taxa de resposta foi de $93,6 \%$. Todas as faculdades recomendam livros especificos, e nenhuma delas possui departamento de Cariologia. Todas as faculdades do pais contemplam em suas disciplinas conteúdos relacionados à Cariologia, distribuídos em disciplinas específicas (exceção da região Norte) e disciplinas dos três ciclos de aprendizagem (básico, clínico e de saúde coletiva), havendo maior carga horária no ciclo clínico. Embora as faculdades publicas de Odontologia do Brasil demonstrem o compromisso curricular de abordarem conteúdos de Cariologia em suas disciplinas, a ênfase no ciclo clinico pode não estar promovendo a formação integrada dos estudantes, o que poderia estar contribuindo para refletir as desigualdades da doença no pais.

\section{Acknowledgements}

The study was supported by a scholarship to the first author granted by The São Paulo State Research Foundation - FAPESP (Grants 2009/12370-1 and 2011/24042-9).

\section{References}

1. Petersen PE, Bourgeois D, Ogawa $\mathrm{H}$ et al. The global burden of oral diseases and risks to oral health. Bull World Health Organ 2005;83:661669.

2. Narvai PC, Frazão P, Roncalli AG et al. Dental caries in Brazil: decline, polarization, inequality and social exclusion [in Portuguese]. Rev Panam Salud Publica 2006;19:385-393.

3. Schulte AG, Momeni A, Pieper K. Caries prevalence in 12-yearold children from Germany. Results of the 2004 national survey. Community Dent Health 2006;23:197-202.

4. Steiner M, Menghini G, Marthaler TM et al. Changes in dental caries in Zurich school-children over a period of 45 years. Schweiz Monatsschr Zahnmed 2010;120:1084-1104.

5. Schulte $A G$, Pitts NB, Huysmans MC et al. European core curriculum in cariology for undergraduate dental students. Caries Res 2011;45:336345.

6. Schulte $A G$, Buchalla $W$, Huysmans MC et al. A survey on education in cariology for undergraduate dental students in Europe. Eur J Dent Educ 2011b;15(Suppl 1):3-8.

7. Bonecker M, Pucca Jr GA, Costa PB, Pitts N. A social movement to reduce caries prevalence in the world. Braz Oral Res 2012;26:491-492.

8. Costa SM, Abreu MHNG, Vasconcelos RCGS, Verdi M, Ferreira EF. Inequalities in the distribution of dental caries in Brazil: a bioethical approach [in Portuguese]. Cienc Saude Coletiva 2013;18:461-470.

9. Clark TD, Mjör IA. Current teaching of Cariology in North American Dental Schools. Oper Dent 2001;26:412-418.

10. Fontana M, Horlak D, Sharples S et al. Teaching of cariology in U.S. dental schools. J Dent Res 2012;91(Spec Iss A):abstract 313.

11. Fukushima M, Iwaku M, Mjör IA. Cariology in Japanese dental schools. Int Dent J 2004;54:269-272.

12. Martignon S, Gomez J, Tellez M et al. Current Cariology educational in dental schools in spanish-speaking Latin American Countries. J Dent Educ 2013;77:1330-1337.

13. Federal Council Dentistry. 2013. Available from <http://www.cfo.org. br> Latest access: November 10, 2013.

14. Brazil. Law No. 12.527, November 18, 2011. Establishing the Access to Information Act. Official Gazette 2011.

15. Anastasiou LGC. The teaching in higher education: challenges and possibilities. ForGRAD em Rev 2006;1:5-8.

16. Brazil. Ministry of Health. Secretariat for Health Care. Department of Primary Care. Coordination of Oral Health. Guidelines of the National Oral Health Policy. Brasilia, 2004.

17. Toassi RFC, Stobäus CD, Mosquera JJM, Moysés SJ. Integrated curriculum for teaching dentistry: new directions for training in the field of healthcare [in Portuguese]. Interface 2012; 16:529-542.

18. Saliba NA, Moimaz SAS, Chiaratto RA, Tiano AVP. The use of PBL methodology in Dentistry: displaying new possibilities for the teaching-learning process [in Portuguese]. Rev Odonto Ciência 2008;23:392-396.

19. Brazil. Ministry of Health. Ministry of Education. Reorientation Program for Professional Training in Health - PRO-HEALTH. Objectives, Implementation and Development Potential. Brasília, 2007. 